\title{
---Introduction and Overview
}

\author{
Timothy Besley ${ }^{1}$ \\ London School of Economics \\ It is ideas, not vested interests, which are dangerous for good or evil. \\ John Maynard Keynes (1883-1946)
}

Lord Keynes' much-quoted epigram serves on three levels as a prologue to the essays gathered in this volume. Like the authors, Keynes was an economist turned practitioner -- the leading one of his day. A pioneer in moving between the worlds of ideas and policy, he was an architect of the Bretton Woods system, and thus of the World Bank which has fostered these contributions. More immediately, his observation gives special relevance to this collection's raison d'etre: the presentation of ideas within a debate on their relevance in the modern world.

Among those ideas, the Washington Consensus stood out at the beginning of the 1990s as a view of what constituted good policy for growth and development. Both the IMF and World Bank had pushed elements of the consensus, particularly the virtue of openness through tariff reduction and privatization as preconditions for adjustment assistance. The practitioners whose essays appear here were invited to reflect on the lessons of the 1990s and to apply critical analysis to their own experiences during the decade dominated by the Washington Consensus. Having had the opportunity to put its ideas into practice, they are well placed to describe what worked and, as policy-makers at the highest level, to help readers judge whether the prevailing ideas of the 1990s were indeed "for good or evil."

The organizers of the lecture series behind this book made no attempt to set the agenda for these practitioners, to coordinate the contributions or make them representative either geographically or in terms of the policy challenges of the era. As printed, the essays are only lightly edited; they represent the raw reflections of their authors. This introduction - by an academic economist - aims at bringing some of the contributors' themes together. It also seeks to provide a context for the essays, relating them to some of the major academic and policy themes from the 1990s onwards and connecting the specific contributions to broader debates.

This group of practitioners comes from the mainstream development community -- part of the international elite many of whom are educated at a small number of elite institutions. ${ }^{2}$ They share in common an exposure to mainstream

\footnotetext{
${ }^{1}$ Professor of Economics and Political Science, LSE. Introductory chapter to Development Challenges in the 1990s: Leading Policy Makers Speak From Experience edited by Timothy Besley and Roberto Zagha for the World Bank. I am grateful to Robin Burgess, Indermit Gill, Todd Pugatch, Robert Wade, and Roberto Zagha for comments and discussion.

${ }^{2}$ While, it is apparent that the policy-makers entered the fray with many shared convictions, it less clear how much their views have been changed by they have seen. Insights into such epiphanies are only occasional, but, in general, it is striking how
} 
thinking in economics and a common set of international institutions (including the World Bank and IMF) frequently viewed as guardians of the particular policy paradigm dominated by the Washington Consensus. Their essays, accordingly, contain little in the way of radicalism or criticism levelled at the world order. ${ }^{3}$ For the most part, the sense is reinforced by the commentators on the lectures whose comments are also printed here.

This volume is not just about the nuts and bolts of policy-making; the essays are equally about ideas. As well as dealing with important economic issues, they reinforce the importance of thinking about history, politics, and institutions in understanding development. This broad-based approach to development thinking sits well with the Pioneers in Development volume of twenty years ago.

The essays reflect the individual style and expertise of each contributor. They draw on experiences from all over the world and deal with a variety of different policy issues, among which two overall modes can be distinguished. The first is proactive policy-making, cases where policy - as in China's gradualist pursuit of planned economic reform -- fosters internally motivated purposive change. The second mode is reactive, a description of policy-making episodes in response to specific events, for example, in Russia after the fall of communism.

The first two essays by Summers and Williamson are not based on specific country experiences, but are the fruit of wide-ranging policy experience in international policy-making by two former academic economists. The remaining authors draw largely from their own country-specific policy experience. There are two such essays on Europe -- Gaidar on Russia and Dervis on Turkey. From Latin America, come Cardoso on Brazil, Aninat and Foxley on Chile, and Blejer on Argentina. Dervis and Blejer deal with crisis management, while Foxley discusses more general themes of macro-economic management. Aninat and Cardoso are concerned more with issues of social development and its link to economic development. Gaidar discusses Russia's transition from a socialist to capitalist economy.

Asia is represented by its two giants. Ahluwalia surveys Indian economic reform, and Zhou does the same in China. These are extremely important case studies, since sustained economic growth in these countries is likely to have a major impact on global poverty. Both have pursued gradualist paths toward economic reform beginning from highly complex and heavily regulated initial conditions. Both have also sought greater integration into the global economy. But the political and social institutions of these countries are very different, and it is clear from the essays that these structures have profoundly influenced the policy process. Nonetheless, both countries are now generally viewed as success stories, even if they face significant policy challenges in years to come.

little self-criticism the essayists voice. No authors said that they got it wrong, and reference to policy error is largely muted.

${ }^{3}$ That said, Dervis does note the problems, as a practitioner, of dealing with the Bretton Woods institutions when the latter are seen primarily as agents of the G7. There is also a note of skepticism in Botchwey's assessment of the array of initiatives on Africa that have, so far, made little headway against poverty in the region. 
Finally, two essays offer more in the way of comparative experience than analyses of specific countries. Although Balcerowicz is from Poland, his essay looks at the broad experience of post-socialist transition in Eastern Europe drawing lessons for this whole group of countries. Similarly, Botchwey takes a broad perspective on development issues in Africa from his Ghanaian vantage point.

In his opening essay, Williamson offers a retrospective on the Washington Consensus -- a concept that he formulated to describe a particular set of economic policies about which he perceived agreement among the World Bank, the IMF and the U.S. Treasury in the late 1980s. As Williamson makes clear in his essay, the term has been widely abused. Many commentators have taken the license of attributing to the consensus some policies that were not on Williamson's original list. Moreover, in some quarters, the words "Washington Consensus" have become a pejorative term to describe a certain kind of free-market economics often (misleadingly) referred to as neo-liberal.

Many elements of the Washington Consensus are anodyne. Few, if any, can doubt the importance of sound fiscal and monetary policy. That said, there are important issues about the right means to the end. It needs to be remembered that the consensus was formulated after a period during which the richer countries began to pull back from flirtations with Keynesian demand management. During the 1970s, the world's richer nations had experienced bouts of stagflation that had dented confidence in the post-war Keynesian consensus. These episodes lead to pessimism about the capacity of government to fine-tune the economy and undoubtedly fuelled the more classical view of the role of monetary policy, which was given its intellectual underpinnings by Milton Friedman and Robert Lucas. The consensus tried to distil these lessons on a more global scale.

Intellectual fashion may play some role here. But serious macro-economic imbalance has proven repeatedly to be the hand-maiden of economic crises and social unrest throughout the developing world. The experiences described by Dervis and Blejer in their essays show just how difficult it is for a country emerging from a period of sustained macro-economic imbalance to concentrate on issues of long-run development. The energy of policy-makers is absorbed in focussing on issues of immediate relevance. The discussions here underline the need to avoid key vulnerabilities that precipitate crises: overvalued exchange rates, excessive fiscal deficits and poorly regulated financial systems, for example. Only when crises are avoided can essential issues of long-run development take center stage in the policy arena.

Apart from macro-economic and monetary stability, one central ingredient of the policy recipe advocated by the Washington Consensus was the need to strengthen property rights as a means of improving the investment climate. While it can be overstated as a sufficient condition for growth, this precept, too, is fairly uncontroversial. $^{4} \quad$ A sizeable body of empirical work, both micro-economic and

\footnotetext{
${ }^{4}$ Even though China does not have a formal system of private property, many of the institutional reforms used in China have replicated the incentives for investment afforded with private property.
} 
macro-economic, now bears out the links between property rights and improved economic performance.

The Washington Consensus also offered fairly uncontentious recommendations on taxation and public spending -- emphasizing the merits of broadbased taxation in financing public spending targeted towards the poor. With hindsight, this recommendation lacked any engagement with the problem of service delivery to ensure that the poor benefit from public expenditures. At the time the more technocratic notion of "targeting" was riding high. The institutional foundations of effective service delivery have since taken the spotlight, not least as the subject of the 2004 World Development Report. Cardoso's discussion of social policies in Brazil emphasizes the kind of compact between civil society and state governance which underpins the modern consensus on building effective services that work in the interest of the poor. As discussed below, this technocratic view of policy is symptomatic of a more general weakness of the Washington Consensus approach that focused on policies rather than institutional solutions.

All of the elements of the Washington Consensus mentioned so far are broadly in step with mainstream economic views as they stood then and as they have remained since. None of our policy-makers takes issue with them.

The two most controversial elements of the consensus were its emphases on openness and on privatization. The value of openness to trade in goods and services is not hugely controversial. Moreover, the experience of China and India in integrating into the world economy, following on from the East Asian miracle, illustrates the power of openness in practice. Arguably this bout of global integration has provided the most rapid sustained fall in global poverty that the world has ever witnessed (see Besley and Burgess (2003)). But, the current Indian and Chinese efforts toward global integration are not experiments in wholesale trade liberalization, but efforts at generating a carefully managed path towards greater openness.

But just how such integration should take place still provokes debate. The Washington Consensus did reflect a greater scepticism about the usefulness of infantindustry protection as a means to pursuing economic development. The latter was a key part of the mainstream approach to development in the early post-war era. But the Consensus formulation in many ways marked the end of naïve, state-led development strategies which had dominated for a generation. The reversal was fuelled in large part by the concern that controlled-trade regimes created rents and fostered political opportunism. Although such influential commentators as Peter Bauer, Jagdish Bhagwati and Anne Krueger were wise to this defect early on, it took a while for their views to become accepted. The Washington Consensus marked the watershed.

This is not necessarily at odds with assigning an important role to the state in promoting development. Indeed there are powerful theoretical arguments for government intervention based on imperfect information and coordination failure. But putting them into practice is not easy. One of the key issues is how to deal with incentive problems in government so that policy choices conducive to economic development are implemented. For this, the political and administrative prerequisites to economic development need to be understood. Amsden (1989) and Wade (1990) 
provide insightful commentaries on the East Asian experience and the way in which the state fostered development in these cases. However, in spite of such case studies, knowledge of how to build a successful developmental state is still quite limited. Generalizing from this, Hausmann and Rodrik (2002) argue that the key feature of trade policy in successful economies is the way in which it is conditioned on performance.

Even if openness to trade is broadly accepted, whether countries should pursue capital-market liberalization is more controversial. However, as Williamson notes in his essay, this policy approach was not part of the original Washington Consensus. Nonetheless, it did become a widely-accepted part of the "augmented Washington Consensus" which gained prominence and significant policy influence in the 1990s. The subsequent economic crises in Russia, East Asia and Latin America from the late 1990s onward were frequently attributed to unwarranted pursuit of capital market liberalization.

Given controversies that surround capital-market liberalization, it is striking that our policy-makers do not give this issue a huge amount of play. It surfaces in only three essays. Summers observes that many of the problems attributed to capital market openness are really the symptoms of policy errors which subsequently fuelled private speculation. This general theme is echoed in Blejer's discussion of the historical background to the 2002 crisis in Argentina and in Dervis's description of the structural weaknesses underpinning the problems that confronted Turkey. In the longterm Summers does make some important observations on the need to develop more appropriate institutional arrangements for international capital markets.

Endorsement of privatization was one of the more controversial parts of the original consensus. It, above all, created the association between Reaganite and Thatcherite policies -- dubbed neo-liberal in some quarters -- and the Washington Consensus. However, it is important to realize that there were two somewhat distinct privatization agendas that were taking route during this period, each of which has its own controversies.

By the early 1990s, privatization strategies were being pursued throughout the OECD and a number of countries in the developing world. In most cases, this amounted to divestment of private goods production where the theoretical case for public ownership is at its weakest. Calls for privatization also reflected political difficulties in managing public enterprise. Janos Kornai developed the notion of the "soft budget constraint" to describe the difficulties that politicians had in trying to impose financial discipline on publicly owned firms. If anything, democratic government made such problems even more severe, and governments privatized as a form of self-denying ordinance.

But the thrust of privatization goes much deeper. In large parts of the economy -- education, health care, pensions, airline security, and railways -- the divergence between private and social returns may indeed speak in favor of some form of public ownership. In such contexts the assertion of the primacy of private ownership is much more ideological, not based on any strong theoretical or empirical case. The cause of the Washington Consensus was damaged by being associated with 
those who wanted to push privatisation in the social sphere. In places like Chile, this effort was pushed hard, but with mixed success.

In the social policy field, there has, been another form of "privatization by stealth" in the form of increasing involvement of NGOs in public service delivery throughout the developing world. In his essay in this volume, Cardoso praises the role of NGOs in Brazil. However, Botchwey sounds a cautionary note in his discussion of the African experience. He discusses the possibility that long-run dependence on NGOs could inhibit rather than help state development in Africa.

The second (and largely distinct) set of privatization policies came into play following the collapse of communism in Eastern Europe, where the issues faced had little to do with the Washington Consensus. Given the extent of public ownership, privatization was inevitable, and the main issues concerned the structure, speed, and form that it would take. In this case - one of reactive policy-making par excellence -there was little experience to guide mass privatization And there is much debate about which countries in Eastern Europe got it right. Balcerowicz's essay in this volume offers some provocative suggestions. The broad thrust of his argument is that, after recognizing initial conditions, those countries that proceeded with the fastest pace of reform fared best. However, Gaidar reminds us that the pace of reform is not always something over which policy-makers have complete control given other events in the economy.

Both Balcerowicz and Gaidar emphasize the importance of the institutional context in which privatization takes place. The market operates well only with the support of a wide variety of institutions -- judicial and regulatory systems in particular -- many of which work poorly and require time to get going. It seems likely that the size of the recession in the post-socialist transition in Europe after privatization was related to institutional shortcomings. Moreover, gains from privatization in the production of private goods require a reasonable degree of competition in product markets. The extent to which this was true varied greatly.

The discussion of privatization hints at a more general theme that pervades these contributions -- the importance of institutions and institutional change in sustaining development. This subject is a central theme of Summers' essay. He refers both to the importance of building institutions and of efficient political administration as key background factors in the development process. He recognizes that these are difficult issues, but sees grappling with them as unavoidable. In similar vein, Williamson sees insufficient attention to the importance of institutions as a deficiency in his formulation of the Washington Consensus. The oversight is not surprising and greater attention to these issues has been a feature of the development literature in the past fifteen years.

During the 1990s, debates about institutional reform and issues of governance became increasingly central in mainstream economics and the policy sphere. Indeed, the idea that development is about getting institutions right is now widely accepted. There is nothing particularly new in the idea that development and institutional change are closely linked. It was at heart of the Nobel-Prize winning work of 
Douglass North. The current preoccupation with good institutions builds on North's insights. ${ }^{5}$

Even so, the term, institution, is often used quite loosely in policy discussions. Moreover, what is meant by a good institution is vaguer still. Nonetheless, the mantra of good institutions has caught on and has come to dominate contemporary thinking. It crops up throughout the practitioners' contributions to this book. But the literature is only just coming to grips with how to think about institutional change and to build good institutions. Thus, as Summers notes:

"It is a huge challenge to all of us ... to build on the recognition of the importance of institutional development and think as constructively as we can about how to actually develop institutional capacity. Too often, we recognize the insight, propound some platitude about transparency and integrity, and move on."

This truth presents a huge challenge for future progress.

Even so, the focus on institutions shifts debates about development in useful ways. It gets away from discussions about specific policies which were at the core of the Washington Consensus. Thus, it is more easily squared with the notion that a wide variety of approaches can be used to achieve successful growth and poverty reduction. In this sense, it is aligned with Dani Rodrik's influential work on growth strategies. $^{6}$

Rodrik has argued persuasively, that by being couched in the language of policies, the Washington Consensus failed to communicate the broader message that what matters to economic success is creating good incentives for production and distribution of public and private goods. There are many ways -- and many policy measures -- to achieve this broad purpose. The policies of the Washington Consensus irritated those who thought that it was trying to build a monolithic path. Moreover, it is apparent that the history of post-war development illustrates a wide variety of development paths. For example, the current path being pursued in China follows no conventional model. The East Asian economies grew using an entirely different model, and the successful transition economies have used different strategies still.

But in all cases, there is no mystery from an economic point of view. The structural transformation that is economic development can only be achieved by a sustained process of change based on actors who perceive their interest in making that change work through a combination of appropriate public and private incentives which are tailored to the history and institutions of the country in question. While some of the key elements of the Washington Consensus would be part of any such strategy, it came up short as a blueprint for economic development.

\footnotetext{
${ }^{5}$ Institutions are being used here in the sense first suggested by North as the humanly devised constraints that shape social interaction (or more succinctly the "rules of the game").

${ }^{6}$ See, for example, Rodrik (2004) and Rodrik, Subramanian and Trebbi (2002).
} 
The institutional approach puts a lot more weight on policy implementation, and not just on policy choice. As Summers notes:

"(an) overwhelming lesson that I think we have learned in the 1990s, is ...the transcendent importance of the quality of institutions and the closely-related questions of the efficacy of political administration. Well-executed policies that are 30 degrees off are much more effective than poorly-executed policies that are spot on."

This is a reaction to mainstream policy economics which had traditionally taken a rather technocratic view of government. The process of policy formation, then given very little attention, has now become a central concern in the so-called "New Political Economy" literature. The drawbacks of ignoring incentive problems in government became increasingly apparent as the lessons of the 1990s unfolded. The essays printed here frequently lay bare the non-technocratic aspects of policy making. For example, Foxley and Ahluwalia provide vivid illustrations of the political preconditions for reform in Chile and India respectively.

An approach that gives institutions due weight also makes clear why good policies are not always enough. One key illustration throughout this volume is the need to make policies credible. Having a good policy today may be fine, but the real issue often centers on maintaining that policy stance going forward and convincing both the private sector and other branches of government to back the effort. This theme of credible commitment is a persistent theme in North's original work on institutions.

How to establish credibility in practice is far from clear. One possibility is to create institutions, such as independent central banks, that are under more limited state control and hence are less inclined toward opportunistic behaviour by politicians. Another is to structure the political system with appropriate separation of powers and with the right structure of "veto players," i.e. those who hold countervailing authority over policy decisions. ${ }^{7}$

But while institutions are undoubtedly important, the game-theory literature has also emphasized the potential of many outcomes (so-called "multiple equilibria"). This can explain how what Summers calls in his essay a "bank-run mentality" can have policy consequences. In the classic example of a bank run, the bank collapses as investors withdraw their funds even though there is no fundamental problem with the bank's lending portfolio. The collapse becomes a self-fulfilling prophecy. Similar logic has been used to explain balance-of-payments crises. Policy-makers who wish to achieve credibility then have to shift expectations in order to deal with the problems, possibly requiring that they do much more than initiate a policy reform.

Blejer, Foxley and Dervis all discuss their attempts as policy-makers to establish credibility by affecting expectations. As Foxley unequivocally states, "It was clear to us that the first challenge was to build trust and credibility in the new

\footnotetext{
${ }^{7}$ Classic examples are the separation of powers between a president and legislature or a bicameral parliamentary system.
} 
government's ability to govern, that is to say, prove that sound economic policies were at the center of our economic program." This challenge was a particular issue in Chile, where the transition to democracy created a weight of expectation among the citizens. Foxley also emphasizes the importance of credibility in maintaining an ongoing program of policy change, particularly in the public sector.

Credibility in the face of a crisis is also an important theme in Dervis' discussion of his policy-making experience in Turkey. He mentions in particular the difficulties of enhancing credibility by getting key private-sector actors -- organized labor and private investors -- to believe that the policy responses to the Turkish crisis could be sustained.

A focus on institutions also helps in understanding inertia in economics and policy-making. Institutions are clearly harder to change than policies and have strong historical roots, as Gaidar notes in the Russian context. The functioning of institutions is embedded in social structures - for example, traditional relationships of trust between actors. Such trust relationships can be valuable in some institutional settings and counter-productive in others, for example if they lead to organized crime. The process of institutional change is thus more complex than policy change. It needs to work with history and culture - it certainly cannot ignore it.

Human capital is also important in shaping institutional capabilities (see Djankov et al (2003) for discussion). But the role and importance in human capital formation does not get much play in these contributions, the main exception being Aninat's essay on educational reform in Chile. It is increasingly clear that the traditional role for human capital formation in increasing labour market productivity sells short its contribution to the development process. The contributions of human capital to social development (especially to health) and political development are also important.

Giving a central role to the institutional setting in economic development is consistent with a recent body of cross-country evidence. Acemoglu, Johnson and Robinson (2001) and Hall and Jones (1999) are important examples. ${ }^{8}$ They each create measures of institutional quality that they show to be strongly related to aggregate economic performance. The former relate this dimension back to a measure of colonial settlement patterns. They find that countries with more European settlers enjoy better institutional quality today. They argue that short-term colonizers had incentives to set up "extractive” institutions which ultimately inhibit the development process.

Recognizing the historical roots of institutional structures gives further support to Rodrik's contention that each country needs to find its own growth strategy, a theme borne out by the essays on China and India in this volume. Both countries have pursued policy paths that reflect the circumstances they faced at the time. Zhou's discussion of the Chinese experience emphasizes the legacy created by the peculiar set of institutions that China had inherited through the Great Leap Forward (and before). The move toward reform required a strategic disempowerment of state

\footnotetext{
${ }^{8}$ Some of this empirical work is summarized and some broader themes developed under the heading of the "New Comparative Economics" by Djankov et al (2003).
} 
structures to provide incentives for enterprise. In line with North's views, institutional change in the form of decentralization was used to reduce the possibility of state predation by creating competition between localities. The results are dramatic, ushering in one of the most dynamic periods of poverty reduction that the world has seen. In China's case good economic incentives have been provided without democratic institutions and private property rights. But it is hard to draw general conclusions from this accomplishment, and Zhou does not try to do so.

The importance of institutional structure is also clear in Ahluwalia's discussion of Indian liberalization. The policy history that created powerful vested interests in the status quo. In a democratic setting, there was a need to build a need to build a sufficiently broad consensus building as a prerequisite for reform. Thereafter, the reform strategy needs to be sustained through democratic institutions, and despite changes in political administration, there are now clear signs of such continuity.

In contrast to many other countries, India's economic reform is less about institutional change and more about policy reform within a stable institutional environment. While the 1990-91 crisis accelerated the reform process, a process of internally motivated deregulation was underway from the mid-1980s onward. Given the strength of Indian democracy, the liberalization program is more typical of policy reform in richer countries. As such its reform process is atypical of the major policy transitions experienced throughout most of the developing world and discussed by many of the other practitioners.

The essays in this volume deal not only with the design and implementation of policy but also with the authors' contributions to the process. This dual perspective creates important links to political-economy issues which now play a central role in mainstream economic analysis. At the heart of this literature is a concern to understand how political forces shape policy choices and their implementation.

The essays are full of examples of political forces shaping policy-making, clear instances of economic reform occurring on the back of coalition-building with attendant, real compromises sometimes required. In the case of India, Ahluwalia cites the fact that inaction was often due to a lack of consensus between technocrats and politicians. Foxley's discussion of the bargain struck between the Chilean unions is an important example of the importance of coalition formation to pushing reform forward. Dervis, Botchwey and Gaidar echo the theme that effective coalitions are an important precondition to reform. More generally, Cardoso attributes the focus on social development to the action of democratic institutions in creating incentives that force politicians to pay greater attention to what people want.

The political-economy approach serves as a useful antidote to the traditionally technocratic view taken in mainstream economics. The Washington Consensus is mostly couched in terms of policies. But, as Summers mentions, the realization that the policy process matters has been increasing among mainstream economics professionals. He refers specifically to policy administration, but policy formulation is important too.

In assessing and pursuing those concerns, however, it is necessary to distinguish between normal politics -- the cut and thrust of political competition 
through the ballot box in which some benefit at the expense of others -- and more malign elements such as special interest politics and problems of corruption. Normal democratic policies must deal with the political incentives that lead to some groups gaining an upper hand in the political process. Democracy has often imposed patterns of trade protection which do not lead to patterns of redistribution corresponding to reasonable notions of social justice. ${ }^{9} \quad$ As the Indian experience illustrates, policymakers frequently find themselves dealing with vested interests created by past policy favors. Ahluwalia stresses the power that open debate in India had in overcoming this and therefore helped to reach consensus on the path to reform.

Concerns about corruption often take pride of place in debates about governance. In view of this emphasis, it is somewhat surprising that corruption receives so little attention in these essays. This may be because such problems are of less concern to policy-makers than to international institutions. There is a sense from Botchwey that corruption has gained too much focus in discussions of governance. He sounds a cautionary note about paying too much attention to problems of state failure:

"By reducing the problems .. to sui generis corruption and predatory behavior on the part of politicians and other public sector actors, it diverted attention from a study of the real causes of market failure and what was needed to improve the efficiency of nonmarket institutions..."

More generally, it not clear whether corruption is a symptom or cause of underdevelopment. The large body of evidence demonstrating a negative correlation between measures of corruption and economic performance (see, for example, Mauro (1995)) is consistent with either conclusion.

Whichever way the causality runs, corruption is symptomatic of resource misallocation. Moreover, there is now less acceptance of the more benign view of corruption as grease for wheels frozen by overbearing bureaucrats and practices. Corruption can have a generally corrosive effect on the conduct of policy and politics. It undermines faith in government to resolve problems and can lead to arbitrary redistribution of the costs and benefits from state intervention. That said, Botchwey is reminding us that it should be tackled in the context of trying to strengthen public institutions rather than promoting cynicism.

Many recent policy discussions have looked for ways to reorganize government to limit corruption and/or alter policies in ways that anticipate corrupt behavior. Making transparency and accountability the motherhood and apple pie of good governance also places weight on the role of civil society and the media in holding government in check ${ }^{10}$ and suggests a role for effective political competition as a means of improving accountability.

\footnotetext{
${ }^{9}$ Recent advances in political economy have suggested that political systems that make greater use of proportional representation are less likely to use selective redistribution policies -- see Persson and Tabellini (1999).

${ }^{10}$ For example, Djankov et al (2003) argue that greater state ownership of media is associated with higher corruption levels.
} 
Improved governance also refers importantly to a broader effort to improve the role of the state in delivering public services. Not just directly important constituents of well-being, these services are important inputs into enhancing productivity. As argued by Cardoso, effective delivery of social policies is a key aspect of building a stable coalition for growth. The issue is particularly important in a country like Brazil with its historical legacy of inequality. He recognizes the difficulties that arise when economic growth does not bring demonstrable social progress. Similar concerns are echoed in Ahluwalia's discussion of whether Indian economic growth has lead to sustained poverty reduction. Thus, a key component in devising strategies on governance is an understanding of ways to improve public service delivery.

An important related proposal stems from efforts to decentralize public service delivery. The main idea is to enhance accountability by strengthening local decisionmaking so as to reduce waste and corruption on one hand and also allow better targeting to the neediest groups as well. Decentralization is also part of a wider theme of empowerment -- providing poor people with a greater say in the way that the state operates.

The 1990s saw many decentralization experiments around the globe. However, while proponents can muster some promising evidence, the jury is still out. Botchwey, in his assessment of decentralization, is not alone in voicing concerns about the potential ability of local elites to capture local government. There is also evidence that the degree of fragmentation in society crucially affects public-service delivery -- see the discussion in Easterly (2001).

Some parallels characterize the current discussions of decentralization and privatization. There is no sensible answer to the question "should an economy privatize?". It depends on the good or service being privatized, the objective being pursued and the array of complementary institutions in place. Similarly, there is no sensible answer to the question -- "should government be decentralized?" The answer will depend again on what is being decentralized, the objectives of policy-making, the exact institutional structure and the economic and social development of the country in question. The importance of these factors and their variety explain why Botchwey can be sceptical of decentralization initiatives in Africa while Cardoso sees successful decentralization in Brazil as an important aspect of delivering better social policies.

In tune with themes of Dani Rodrik's work on growth strategies, the politicaleconomy literature does not suggest that there is a uniquely optimal set of political institutions, and the practitioners spend little time debating the relative merits of alternative political institutions. But even among the advanced democracies of the world, a wide variety of options operate, and, as recent literature has demonstrated, there is good reason to believe that they can shape the policy process.

Cross-country data show little convincing evidence about the merits of a democratic setting for economic policy outcomes. This is true in spite of the broad consensus on the importance of representative democracy after what Samuel Huntington has called "democracy's third wave". Democracy is no panacea for the problems of economic management. Indeed, many of the dilemmas faced by the policy-makers arose precisely because they operated under democratic constraints. 
Much of the policy-making discussed here is in response to crises. As Blejer points out, policy-making in normal times and in crisis situations is quite different -both in terms of the speed with responses are needed and the type of medicine administered. More generally, the practitioners draw important lessons about crisis management. First, there is a need to monitor critical vulnerabilities and to spot them before they reach crisis proportions. Second, it is vital to develop a strategy and to persist with it. Blejer cautions against always listening to external actors; both he and Dervis discuss how they stood up to the IMF at the height of their crises.

Dervis proffers the bold suggestion that crises are the time to push for fundamental reform. There may be a paradox here heightening the tension between economic and political necessity. Any economist would say that economic reform is most important when it avoids the onset of a crisis. However, the ability to push a reform through the political process is greatest only when the crisis sets in. The question is how to resolve such a real and theoretical tension.

So what are the main lessons?

First and foremost, there is a need to avoid economic crises. They may occasionally prompt radical policy reform that would otherwise be resisted, but for the most part they are a tax on the energy of policy-makers and citizens alike. Those aspects of the Washington Consensus that emphasize sound macro-economic management are as relevant today as when the consensus was formulated.

Second, the policy-makers' reflections show the importance of focusing on specific issues in the policy process to deal with binding constraints. These will vary from country to country and over time, but the successes that are described here demonstrate focus and an eye towards developing a pro-active strategy and not just reacting to events.

Third, the essays illustrate the complexity of policy reform and how there is rarely a simple and stylized fix to problems of economic reform. In coping with complexity, learning is important and understanding the way in which economy gives information about what is being achieved and what more is needed.

Fourth, the essays illustrate the proposition that process matters as well as substance in policy reform. Effective reform involves a lot more than creating “political will”.

Fifth, each country needs to find its own growth strategy from an internally driven process responsive to its institutional capacity and economic conditions. The principal failure of the Washington Consensus was to suggest, perhaps unintentionally, a monolithic view of development strategy. The discussion here of post-communist transition in Eastern Europe and the on-going transformation of India and China drive home the message that paths to development need to be tailored to country-specific institutional capacity. Without the development of a suitably nuanced growth strategy for each country, the African growth (and humanitarian) tragedy will continue to haunt humanity, and the sequence of international initiatives that Botchwey discusses will generate little progress. 
Sixth, the authors' reflections show that institutions matter both as constraints and defining opportunities. But, it would be a mistake to couch this doctrinairely as defining uniquely good institutions for all contexts. Clearly, on the contrary, history and circumstance matter far more than easy generalization.

Finally, the power of ideas is striking -- ideas taught in the classroom to generations of students - in the thinking of the practitioners. They provide a vivid illustration of the increasingly porous boundary between academia and policy-making across which economic ideas travel easily and influence the world. These essays make plain just how extensive and vigorous this commerce has become. But these ideas are constantly being refined in the light of experience (albeit in many cases with a lag). It is to this back and forth between ideas and experience that these essays make a distinctive contribution.

\section{References}

Acemoglu, Daron Johnson, Simon; James A. Robinson, [2001], "The Colonial Origins of Comparative Development: An Empirical Investigation", American Economic Review; 91(5), 1369-1401.

Amsden, Alice, [1989], Asia's next Giant: South Korea and Late Industrialization, New York: Oxford University Press

Besley Timothy and Robin Burgess, [2003], "Halving Global Poverty," Journal of Economic Perspectives, 17(3), 3-22.

Djankov, Simeon, Caralee McLeish, Tatiana Nenova, and Andrei Shleifer, [2001], "Who Owns the Media?" typescript, Harvard University.

Djankov, Simeon, Edward Glaeser, Rafael LaPorta, Florencio Lopez-de-Silanes, [2003], "The New Comparative Economics," typescript, Harvard University.

Easterly, William, (2001): The Elusive Quest for Growth -- Economists' Adventures and Misadventures in the Tropics, The MIT Press

Hall, Robert E and Chad Jones, [1999], "Why Do Some Countries Produce So Much More Output per Worker than Others?" Quarterly Journal of Economics 114, 83-116.

Hausmann Ricardo and Dani Rodrik, [2002], "Economic Development as SelfDiscovery," NBER Working Paper, No. 8952.

Mauro, Paulo, [1995], "Corruption and Growth," Quarterly Journal of Economics, 110(3), 681-712.

Persson, Torsten and Guido Tabellini, (1999), "The Size and Scope of Government: Comparative Politics with Rational Politicians," European Economic Review, 43(1), 699-735.

Rodrik, Dani, [2003], "Growth Strategies," typescript, Harvard University. 
Rodrik, Dani, [2004], "Getting Institutions Right," typescript, Harvard University.

Rodrik, Dani, Arvind Subramanian and Francesco Trebbi, [2002], "Institutions Rule: The Primacy of Institutions over Geography and Integration in Economic Development," typescript, Harvard University.

Shleifer, Andrei and Vishny, Robert, [1998], The Grabbing Hand: Government Pathologies and Their Cures (Cambridge: Harvard University Press)

Wade, Robert, [1990], Governing the Market: Economic Theory and the Role of the State, Princeton: Princeton University Press.

Williamson, John [2000], "What should the Bank think about the Washington Consensus?", Background Paper for 2000 World Development Report, available at http://www.iie.com/papers/williamson0799.htm. 